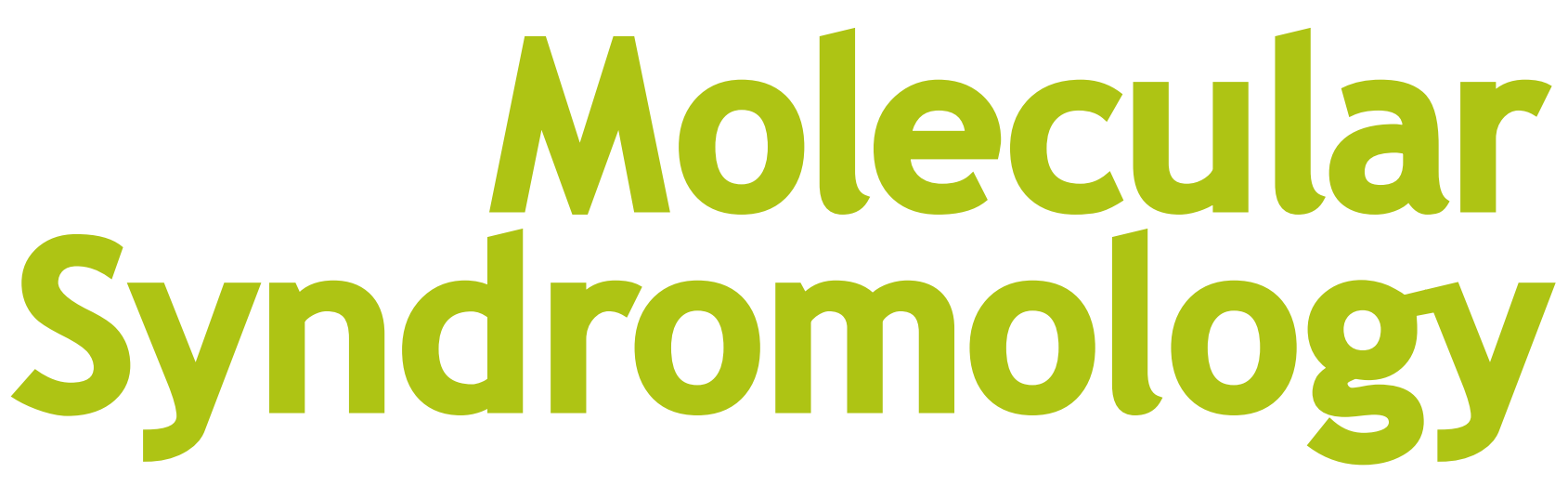

\title{
VACTERL Association
}

Editor

Benjamin D. Solomon, Bethesda, Md.

Medical and Scientific Publishers Basel · Freiburg · Paris

London - New York ·

New Delhi · Bangkok · Beijing ·

Tokyo · Kuala Lumpur .

Singapore $\cdot$ Sydney
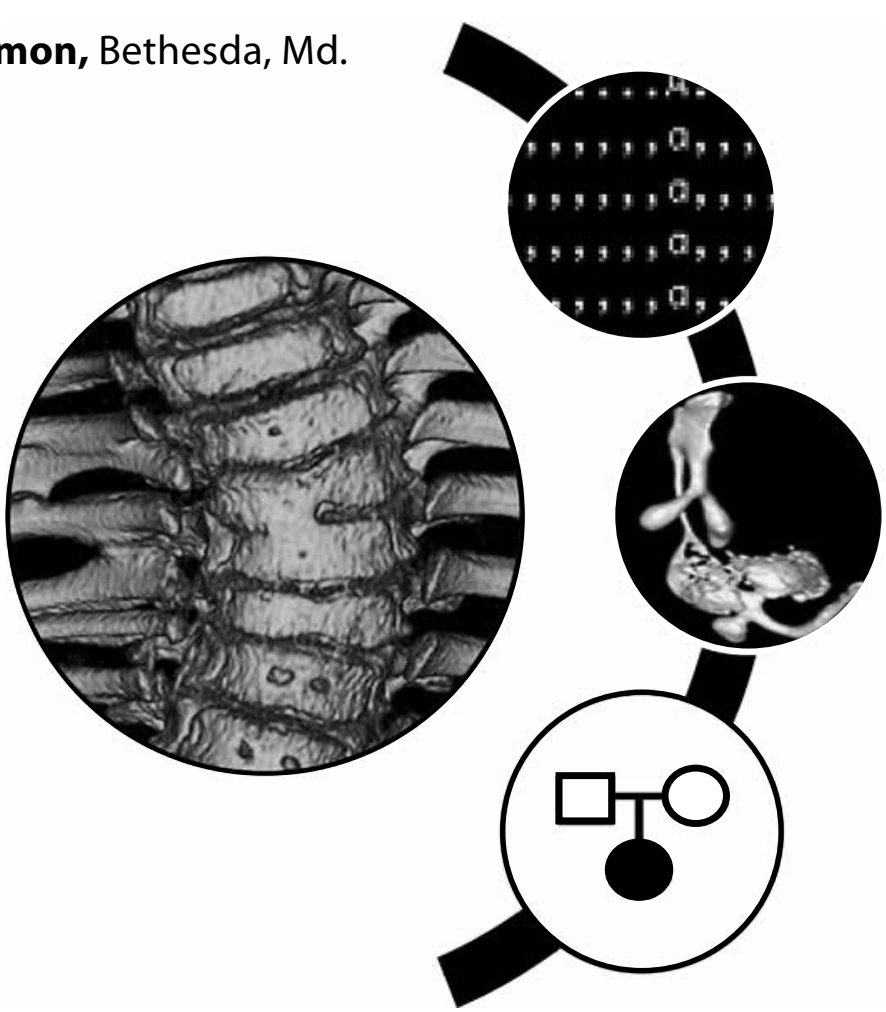


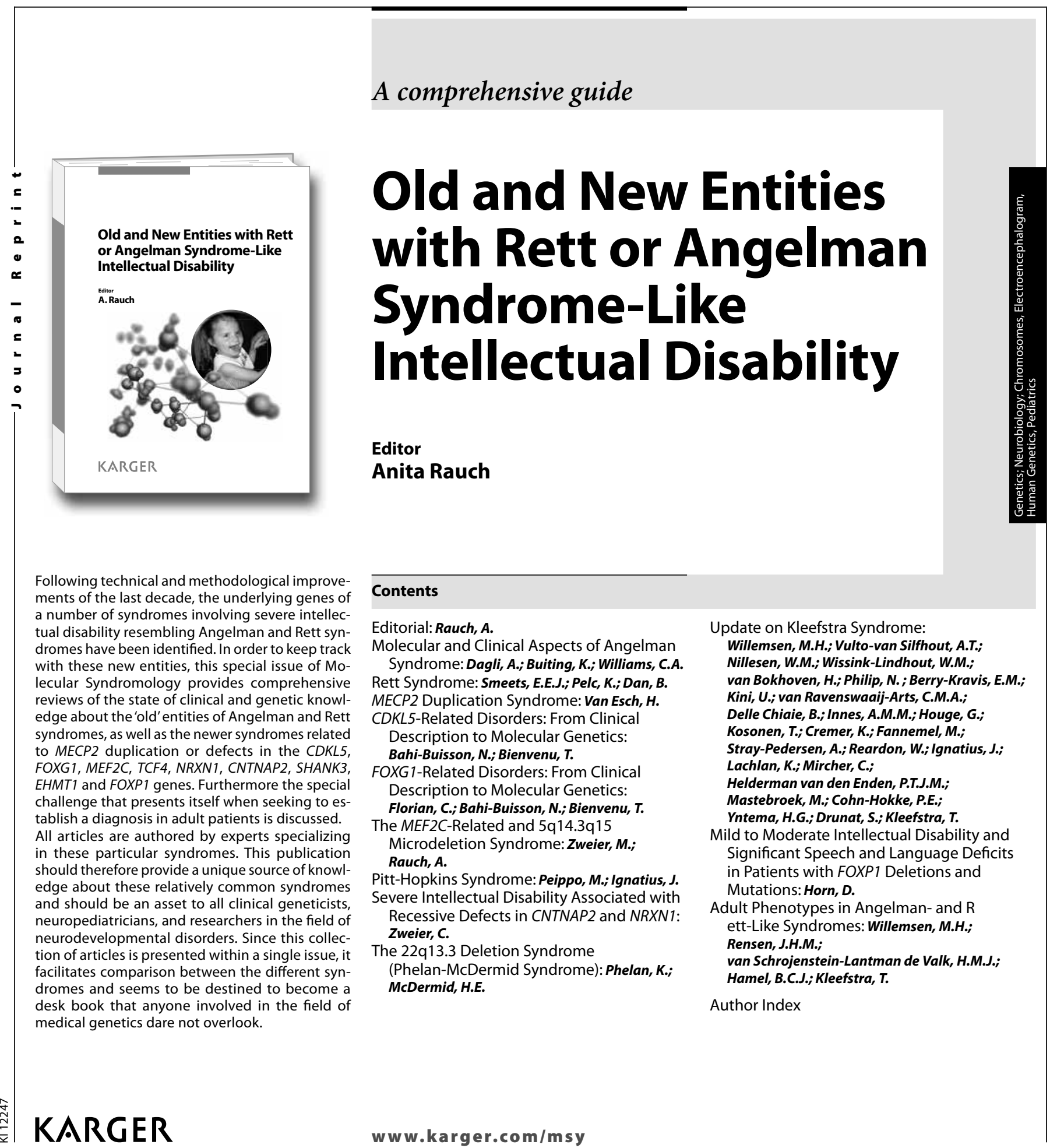

Old and New Entities with Rett or Angelman Sydrome-Like Intellectual Disability Editor: Rauch, A. (Zurich)

142 p., 28 fig., 22 in color, 27 tab., hard cover, 2012 CHF 79.- / EUR 66.- / USD 93.00

Prices subject to change

EUR price for Germany, USD price for USA only

ISBN 978-3-8055-9968-9

e-ISBN 978-3-8055-9969-6

Hard Cover Reprint:

Molecular Syndromology

Vol. 2, No. 3-5 (2011)

Not included in subscription

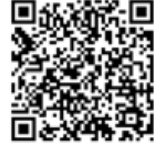

pdate on Kleefstra Syndrome:

Stray-Pedersen, A $\cdot$ Reardon, W.; Ignatius, J.;

achlan, K.; Mircher, $C$.;

ild to Moderate Intellectual Disability and

Significant Speech and Language Deficits in Patients with FOXP1 Deletions and ions: Horn, $D$.

van Schrojenstein-Lantman de Valk, H.M.J.

el, B.C.J.Kleefstra, T.

Fax: +41613061234

S. Karger AG, P.O. Box, CH-4009 Basel (Switzerland)

E-Mail orders@karger.ch,www.karger.com

$\boldsymbol{\varepsilon}$

Postage and handling free with prepayment

Please charge to my credit card

- $\square$ American Express $\square$ Diners

ᄂ $\square$ MasterCard $\square$ Visa

- Card No

O Exp date:

- CVV/CVC

( 3 digits in the signature field on the back of Visa and MasterCard)

$\square$ Check enclosed $\quad \square$ Please bill me

Orders may be placed with any bookshop, subscription agency, directly with the publisher or through a Karger distributor.
Name/Address:

Date: 


\section{Molecular
Syndromology \\ Molecular
Syndromology}

\section{Editors-in-Chief}

Lisa G. Shaffer

CEO, Paw Print Genetics

a division of Genetic Veterinary Sciences, Inc.

850 E Spokane Falls Blvd, Suite 200

Spokane, WA 99202 (USA)

Office: +1 5094835950

Mobile: +1 5097237879

E-Mail lshaffer@pawprintgenetics.com

\section{Michael Schmid}

Department of Human Genetics

University of Würzburg

Biozentrum, Am Hubland

D-97074 Würzburg (Germany)

Tel. (+49) 931318 4077; Fax (+49) 9313184058

E-mail: m.schmid@biozentrum.uni-wuerzburg.de

\section{Managing Editors}

Martina Guttenbach (address as for M. Schmid) E-mail: guttenbach@biozentrum.uni-wuerzburg.de

Melanie Zimmermann (addr. as for M. Schmid) E-mail: melanie.zimmermann@uni-wuerzburg.de

Tanja Gösswein (address as for M. Schmid)

E-mail: goesswein@biozentrum.uni-wuerzburg.de

\section{Editorial Administrator}

Claus Steinlein (address as for M. Schmid) E-mail:

claus.steinlein@biozentrum.uni-wuerzburg.de

\section{Associate Editors}

\section{Kenjiro Kosaki}

Division of Medical Genetics

Department of Pediatrics

35 Shinanomachi, Shinjuku-ku

Tokyo 160-8582 (Japan)

Tel. +81 3-3353-1211 X62368

Fax +81 3-5379-1978

E-mail: kkosaki@sc.itc.keio.ac.jp

\section{Geert Mortier}

Department of Medical Genetics

Antwerp University Hospital

Prins Boudewijnlaan 43

B-2650 Antwerp (Belgium)

Tel. +32 32759773 (secretary)

Tel. +32 32759766 (direct)

Fax +3232759723

E-mail: geert.mortier@ua.ac.be
Maximilian Muenke

Medical Genetics Branch

National Human Genome Research Institute

National Institutes of Health

35 Convent Drive, MSC 3717

Building 35, Room 1B-203

Bethesda, MD 20892-3717 (USA)

Tel. +1 301402 8167; Fax +1 3014807876

E-mail: mamuenke@mail.nih.gov

Marco Tartaglia

Istituto Superiore di Sanità

Dipartimento di Ematologia, Oncologia e

Medicina Molecolare

Viale Regina Elena, 299

00161 Rome (Italy)

Tel. +39 064990 2569; Fax +390649387143

E-mail: mtartaglia@iss.it

\section{Editorial Board}

Axel Bohring, Münster

Armand Bottani, Genève

Han Brunner, Nijmegen

Hartmut Engels, Bonn

Livia Garavelli, Reggio Emilia

Judith G. Hall, Vancouver

Raoul Hennekam, Amsterdam

Gunnar Houge, Bergen

Wolfram Kress, Würzburg

Martin Poot, Utrecht

Anita Rauch, Zurich

Stephen Robertson, Dunedin

Peter Scambler, London

Ben Solomon, Bethesda, Md.

Karen Temple, Southampton

Annick Toutain, Tours

Miikka Vikkula, Brussels

Bernd Wollnik, Köln
Printed in Switzerland on acid-free and non-aging paper (ISO 9706) by Reinhardt Druck, Basel
Appears bimonthly: 1 volume per year (6 issues) 


\section{Molecular Syndromology}

\section{Molecular Syndromology}

Molecular Syndromology publishes research articles, short reports and reviews on the molecular basis of genetic syndromes, genotype-phenotype correlations, natural history strategies in disease management and novel therapeutic approaches linked to molecular basis.

\section{Publication categories in conventional issues}

Original Articles are high-quality research reports on common and rare genetic syndromes in humans aiming to in crease the clinical understanding through molecular insights. Articles dealing with animal model organisms are also considered.

Reviews covering a timely topic by experts in the field are either invited by the Editors or may be submitted for consideration.

Short Reports must present results of sufficient importance to justify accelerated acceptance. They should not be longer than 2,000 words.

Calls for Collaborative and Interactive Research Projects are contributions from investigators who are in need of research materials, or need the assistance of colleagues with specialized expertise, or who have data that are inadequate for a ful report but which could be published when combined with the data of others.

Commentaries are a forum for observations, opinions, and comments outside the realm of conventional scientific papers. Original data, illustrations and tables may be included.

The illustrative clinical case (max. 1 per issue)

Concise and brief case reports with very short introduction and discussion which do not actually represent new scientific or clinical insights but which are illustrative regarding the clinical representation.

Stucture: No abstract, introduction limited to 200 words, illustrative case report including laboratory findings, short discussion.

Brief Mutation Report

Brief reports on mutations and associadet phenotypes which are helpful for genotype-phenotype correlations but without major new scientific insights; very short introduction and discussion.

Structure: No abstract, introduction limited to 200 words, case report including laboratory findings, short discussion.

\section{Single topic issues}

The journal also publishes a series of themed issues. For these volumes we solicit the assistance of one or more expert investigators to act as Guest Editor(s) in an area that is particularly interesting and/or one in which there is a need for a thorough overview. The Guest Editors invite top researchers to contribute original research reports or reviews of a topic that is in their main area of interest. These manuscripts are peer-reviewed in the same way as papers received for conventional issues. Proposals clearly outlining a theme and nominating potential Guest Editor(s) are welcome.

\section{Submission}

Only original papers written in English and conforming to the 'Guidelines for Authors' will be considered for publication. They should be submitted using the online website at:

\section{www.karger.com/msy}

Should you experience any problems with your online submission, please contact:

\section{Claus Steinlein}

Department of Human Genetics

University of Würzburg

Biozentrum, Am Hubland

D-97074 Würzburg (Germany)

Tel. (+49) 931318 8091; Fax (+49) 9313184058

E-mail: claus.steinlein@biozentrum.uni-wuerzburg.de

All manuscripts are subject to editorial review. Names, postal and e-mail addresses of three experts in the appropriate area of research should accompany each manuscript. The referees suggested should not be from the same institution as the author(s) and are expected to have expert knowledge of the subject. The Editors reserve the right to appoint referees different from those suggested by the corresponding author.

The Editors reserve the right to improve style and, if necessary, return the manuscript for rewriting to the authors.

\section{Conditions}

The manuscript must be accompanied by a cover letter stating that all authors have seen and given their approval for submission of the manuscript to Molecular Syndromology. Manuscripts are received with the explicit understanding that they are not under simultaneous consideration by any other publication or have not already been published elsewhere. Submission of an article for publication implies transfer of the copyright from the author to the publisher upon acceptance. Accepted papers become the permanent property of Molecular Syndromology and may not be reproduced by any means, in whole or in part, without the written consent of the publisher

It is the authors' responsibility to obtain permission to reproduce texts, illustrations, tables, etc., from copyrighted sources.

The Editor reserves the right to reject papers based on priorities and space availability in the journal. Manuscripts that do not comply with the ethical standards recommended by the Helsinki Declaration will not be accepted.

Published Conflict-of-Interest

Manuscripts are received with the explicit understanding that they are not under simultaneous consideration by an other publication or have not already been published elsewhere.

\section{Published Statement of Informed Consent}

The manuscript must be accompanied by a cover letter stating that all authors have seen and given their approval for submission of the manuscript to 'Molecular Syndromology'.

Published Statement of Human and Animal Rights

Manuscripts that do not comply with the ethical standards recommended by the Helsinki Declaration will not be accepted.

\section{Arrangement}

Title page: The first page should contain the title of the article along with an appropriate running title, the full names of the authors and their affiliations. The full postal address, telephone and fax numbers, as well as the e-mail address of the corresponding author must also be included.

Abstracts should be provided for all Original Articles, Reviews and Short Reports.

Figures: Digital illustrations should be sharp with good con trast and color rendition. Resolution for all graphics should be at least $300 \mathrm{dpi}$. We request that all illustrations be in common format such as .jpg (.jpeg .jpe), .tif (.tiff), .eps or .ppt Tables must be in Word format. Please use MS WORD Table $>$ Insert > Table command from the menu bar to make tables.

\section{Literature Cited}

References should be quoted in the text as follows: single author: Jones (1999); two authors: Jones and Smith (2000); more than two authors: Jones et al. (2001). The reference list should be arranged alphabetically according to the first author's surname. Titles should be given in full. Papers published in electronic format exclusively should list authors, title and journal as above followed by the journal's URL, e.g.: Chinnappan D, Zhang Y, Ravid K: AIM-1 Transgenic mice with a curly tail phenotype and its chromosome location. $\mathrm{Cy}$ togenet Genome Res 98:231A (2002) at: http://karger.com/ doi/ 10.1159/000069799.

Book references must include the book title, editor(s), publisher, and city of publication. Recent issues of the Journal should be carefully consulted for reference list style. Agreement between text citations and the reference list should be checked carefully, and the latter checked for accuracy. If many errors are found, the manuscript will be returned for corrections which may cause considerable publication delay.

\section{Gene Symbols}

Human gene symbols: Only official gene symbols assigned by the HUGO Gene Nomenclature Committee (HGNC) are accepted. Authors must obtain or verify the official gene symbol of the gene(s) mapped and indicate that they have done so in the manuscript submitted. This can be accomplished for human genes by contacting

HUGO Gene Nomenclature Committee (HGNC)

European Bioinformatics Institute (EMBL-EBI)

Wellcome Trust Genome Campus

Hinxton, Cambridgeshire, CB10 1SA, UK

E-Mail: hgnc@genenames.org

Website: www.genenames.org

Guidelines set forth by the HUGO Gene Nomenclature Committee are available at www.genenames.org/guidelines. html

New symbols and names for genes can be requested electron ically through the online gene symbol request form at http:// www.genenames.org/cgi-bin/hgnc_request.pl

Animal gene symbols: Authors submitting material on mouse and rat genetics should obtain correct genetic nomenclature before publication.

\section{Lois Maltais}

MGD Nomenclature Coordinator

The Jackson Laboratory

600 Main Street

Bar Harbor, ME 04609, USA

Tel. +1 2072886429

Fax +1 2072886132

E-Mail: nomen@informatics.jax.org

MGD home page: www.informatics.jax.org

Guidelines set forth by the International Committee on Standardized Genetic Nomenclature for Mice are available at www.informatics.jax.org/mgihome/nomen/table.shtm New symbols and names for genes can be requested electronically through the on-line symbol registry form at www. informatics.jax.org/mgihome/nomen.

Gene mapping data for the mouse should also be submitted to the Mouse Genome Database (MGD) following the guidelines at www.informatics.jax.org/mgihome/submissions/submit.shtml. The assigned MGD accession number should be included in the manuscript for publication. Assistance with submissions can be obtained by sending an e-mail to: submissions@informatics.jax.org

Guidelines for the Use of Cell Lines in Cancer Research Guidelines published by the United Kingdom Coordinating Committee on Cancer Research may be downloaded from the NCRN website at: http://www.ncrn.org.uk/csg/publications.htm

\section{Electronic Proofs}

Unless indicated otherwise, proofs are e-mailed to the corresponding author

\section{Color Charges}

There are no charges for illustrations and color reproductions.

\section{Page Charges}

No page charges are levied.

\section{Supplementary Material}

Supplementary material is restricted to additional data that are not necessary for the scientific integrity and conclusion of the paper. Please note that all supplementary files will undergo editorial review and should be submitted together with the original manuscript. The Editors reserve the right to limit the scope and length of the supplementary material. Supplementary material must meet production quality standards for Web publication without the need for any modification or editing. In general, supplementary files should not exceed $10 \mathrm{MB}$ in size. All figures and tables should have titles and legends and all files should be supplied separately and named clearly. Acceptable files and formats are: Word or PDF files Excel spreadsheets (only if the data cannot be converted properly to a PDF file), and video files (.mov, .avi, .mpeg).

\section{KARGER}

E-Mail karger@karger.com www.karger.com
(C) 2013 S. Karger AG, Basel 


\section{Molecular Syndromology}

Author's Choice ${ }^{\mathrm{TM}}$

Karger's Author's Choice ${ }^{\mathrm{TM}}$ service broadens the reach of your article and gives all users worldwide free and full access for reading, downloading and printing at www.karger.com. The option is available for a one-time fee of CHF 3000.-, which is a permissible cost in grant allocation. More information can be found at www.karger.com/authors_choice.

\section{NIH-Funded Research}

The U.S. National Institutes of Health (NIH) mandates under the NIH Public Access Policy that final, peer-reviewed manuscripts appear in its digital database within 12 months of the official publication date. As a service to authors, Karg er submits the final version of your article on your behalf to PubMed Central. For those selecting our premium Author's Choice ${ }^{\mathrm{TM}}$ service, we will send your article immedi- ately upon publishing, accelerating the accessibility of your work without the usual embargo. More details on NIH's Public Access Policy is available at http://publicaccess.nih.gov/ FAQ.htm\#a1

\section{Self-Archiving}

Karger permits authors to archive their pre-prints (i.e. prerefereeing) or post-prints (i.e. final draft post-refereeing) on their personal or institution's servers, provided the following conditions are met: Articles may not be used for commercial purposes, must be linked to the publisher's version, and cial purposes, must be linked to the publisher's version, and
must acknowledge the publisher's copyright. Authors selecting Karger's Author's Choice ${ }^{\mathrm{TM}}$ feature, however, are also permitted to archive the final, published version of their article which includes copyediting and design improvements as well as citation links.

\section{Reprints}

Reprints are available against payment. Order forms listing prices are provided with the proofs. If no reprints are desired this should be indicated on the form. Orders submitted after the issue has gone to press are subject to higher prices.

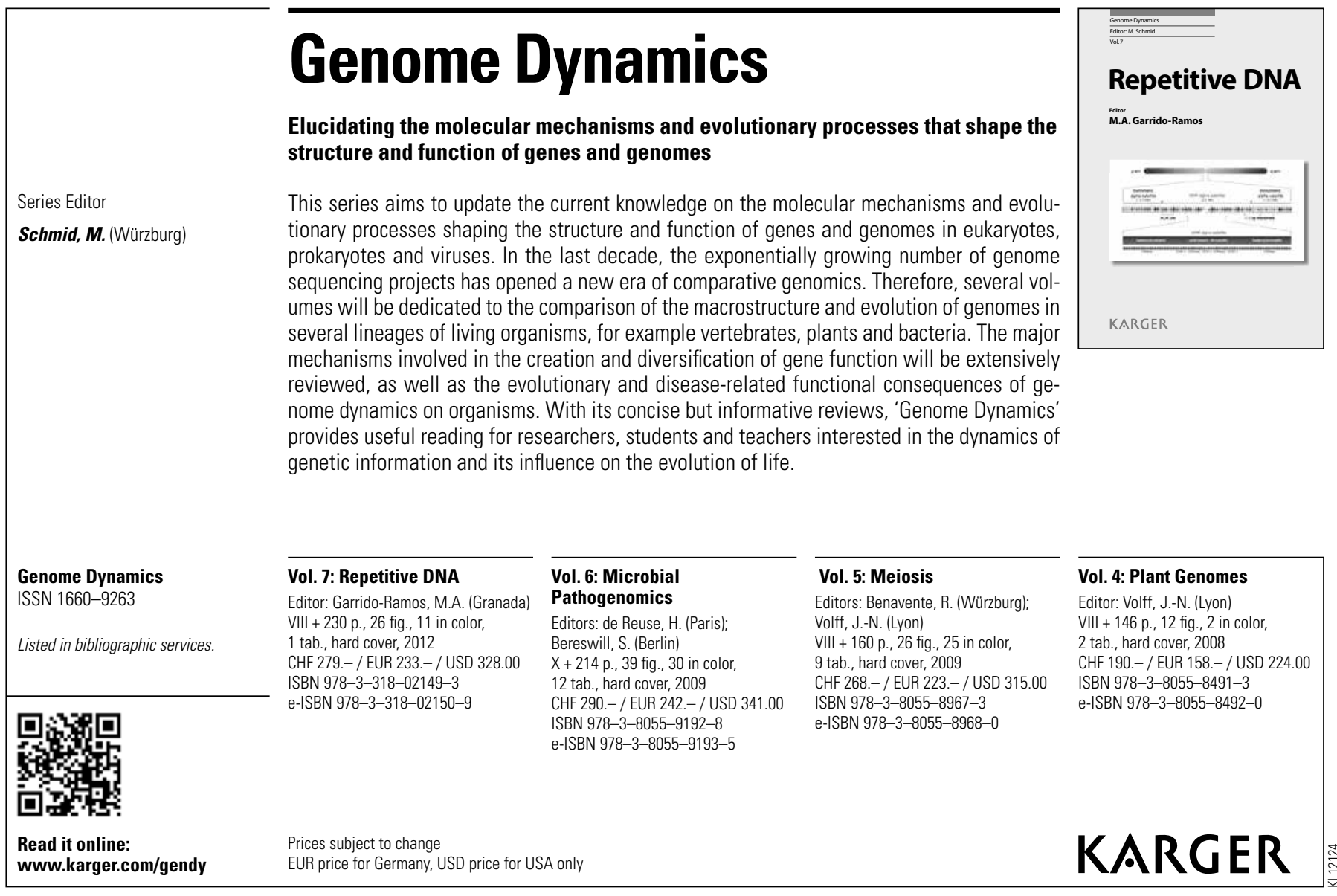

\section{KARGER}

E-Mail karger@karger.com www.karger.com
(C) 2013 S. Karger AG, Basel

The Journal Home Page is available at: www.karger.com/msy 


\section{Molecular Syndromology}

ISSN Print Edition: 1661-8769

ISSN Online Edition: 1661-8777

Journal Homepage: www.karger.com/msy

Publication Data: 'Molecular Syndromology'. Volume 4 with 6 issues appears in 2013.

Copyright: (c) 2013 S. Karger AG, Basel (Switzerland). All rights reserved. No part of this publication may be translated into other languages, reproduced or utilized in any form or by any means, electronic or mechanical, including photocopying, recording, microcopying, or by any information storage and retrieval system, without permission in writing from the publisher or, in the case of photocopying, direct payment of a specified fee to the Copyright Clearance Center.

Disclaimer: The statements, opinions and data contained in this publication are solely those of the individual authors and contributors and not of the publisher and the editor(s). The appearance of advertisements in the journal is not a warranty, endorsement, or approval of the products or services advertised or of their effectiveness, quality or safety. The publisher and the editor(s) disclaim responsibility for any injury to persons or property resulting from any ideas, methods, instructions or products referred to in the content or advertisements.
Subscription Rates: Subscriptions run for a full calendar year. Prices are given per year.

Personal subscription:

CHF 757.

EUR 611.-

Print+Online combined

CHF 805.-

USD 750.00

EUR 650.-

ostage and handling (added to print and print+online)

CHF 43.20 Europe, CHF 62.40 Overseas

EUR 33.60

USD 57.60

Institutional subscription:

Print or Online

Print+Online combined

CHF 1514.

EUR 1221.-

CHF 1665.-

USD 1499.00

postage and handling (added to print and print+online)

CHF 54.- Europe, CHF 78.- Overseas

EUR 42.00

USD 72.00

Airmail surcharge: CHF 52.50 / USD 49.50
Back Volumes and Single Issues: Information on availability and prices of single print issues and print or electronic back volumes can be obtained from Customer Service atservice@karger.com.

Bibliographic Indices: This journal is regularly listed in Index Medicus/MEDLINE, Science Citation Index, EMBASE/Excerpta Medica, IMEMR (WHO) and Reference Update.

Photocopying: This journal has been registered with the Copyright Clearance Center (CCC), as indicated by the code appearing on the first page of each article. For readers in the US, this code signals consent for copying of articles for personal or internal use, or for the personal or internal use of specific clients, provided that the stated fee is paid per copy directly to

Copyright Clearance Center Inc.

222 Rosewood Drive

Danvers, MA 01923 (USA)

A copy of the first page of the article must accompany payment. Consent does not extend to copying for general distribution, for promotion, for creating new works, or for resale. In these cases, specific written permission must be obtained from the copyright owner,

S. Karger AG, P.O. Box

CH-4009 Basel (Switzerland).
Subscription Orders:

Orders can be placed at agencies,

bookstores, directly with the Publisher

\section{S. Karger AG}

Medical and Scientific Publishers

P.O. Box

CH-4009 Basel

Switzerland

(for courier services only:

$\mathrm{CH}-4055$ Basel)

t: +41613061111

e: karger@karger.com

w: www.karger.com
Allschwilerstrasse 10

f: +41613061234

\begin{tabular}{|c|c|}
\hline $\begin{array}{l}\text { or further Karger offices } \\
\text { or representatives: }\end{array}$ & $\begin{array}{l}\text { USA } \\
\text { S. Karger Publishers, Inc. } \\
26 \text { West Avon Road }\end{array}$ \\
\hline Germany & P.O. Box 529 \\
\hline S. Karger GmbH & Unionville, CT 06085 \\
\hline Postfach & USA \\
\hline 79095 Freiburg & Toll free: +18008285479 \\
\hline Deutschland & $\mathrm{t}: \quad+18606757834$ \\
\hline (Hausadresse: Wilhelmstrasse 20A, & f: +18606757302 \\
\hline $\begin{array}{l}\text { 79098 Freiburg) } \\
\mathrm{t}: \quad+49761452070\end{array}$ & e: karger@snet.net \\
\hline f: $\quad+497614520714$ & France \\
\hline e: information@karger.de & Librairie Médi-Sciences Sarl \\
\hline w: www.karger.de & $\begin{array}{l}\text { 36, bd de Latour-Maubourg } \\
75007 \text { Paris }\end{array}$ \\
\hline Japan & France \\
\hline Karqer Japan, Inc. & $\mathrm{t}: \quad+33(0) 145514258$ \\
\hline Shiba Daimon Asahi Bldg. 2F & $\mathrm{f:}+33(0) 145560780$ \\
\hline 1-2-23 Shiba Daimon & e: librairie@medi-sciences.fr \\
\hline Minato-ku & w: www.medi-sciences.fr \\
\hline Tokyo $105-0012$ & \\
\hline Japan & \\
\hline t: +81364356242 & \\
\hline f: +81364356244 & \\
\hline e: publisher@karger.jp & \\
\hline w: www.karger.jp & \\
\hline
\end{tabular}

Change of Address:

Both old and new address should be sent

to the subscription source.

\section{KARGER}

E-Mail karger@karger.com www.karger.com
(C) 2013 S. Karger AG, Basel

The Guidelines for Authors are available at: www.karger.com/msy_Guidelines
South East Asia, China and Taiwan Karger Regional Office (Malaysia)

CEO Suite Kuala Lumpur

Quill 7, 27th Floor

Jalan Stesen Sentral 5

KL Sentral

Kuala Lumpur 50470

Malaysia

t: +60327766803

f: +6032776699

e: service@karger.cn; r.chew@karger.cn

Karger China

10th Floor, Twin Towers (East)

B12 Jianguomenwai Avenue

Beijing 100022

$\mathrm{t}:+861051235033$

f: +861051235122

e: service@karger.cn; r.chew@karger.cn

w: www.karger.cn

India, Bangladesh, Sri Lanka

Medscience India

Plot No. 17, Yusuf Sarai Market

B.L. Glass Building, 2nd Floor

Sri Aurobindo Marg

New Delhi 110016

India

t: +911146029633

f: +911146029634

c: +919891052128

e: medsci.india@gmail.com 


\section{Contents}

See the journal website for contents

KARGER Basel $\bullet$ Freiburg $\cdot$ Paris $\bullet$ London $\bullet$ New York $\cdot$ New Delhi $•$ Bangkok Beijing $\cdot$ Tokyo $\cdot$ Kuala Lumpur $\cdot$ Singapore $\bullet$ Sydney 
Joint Conference of HGM 2013 and $21^{\text {st }}$ International Congress of Genetics
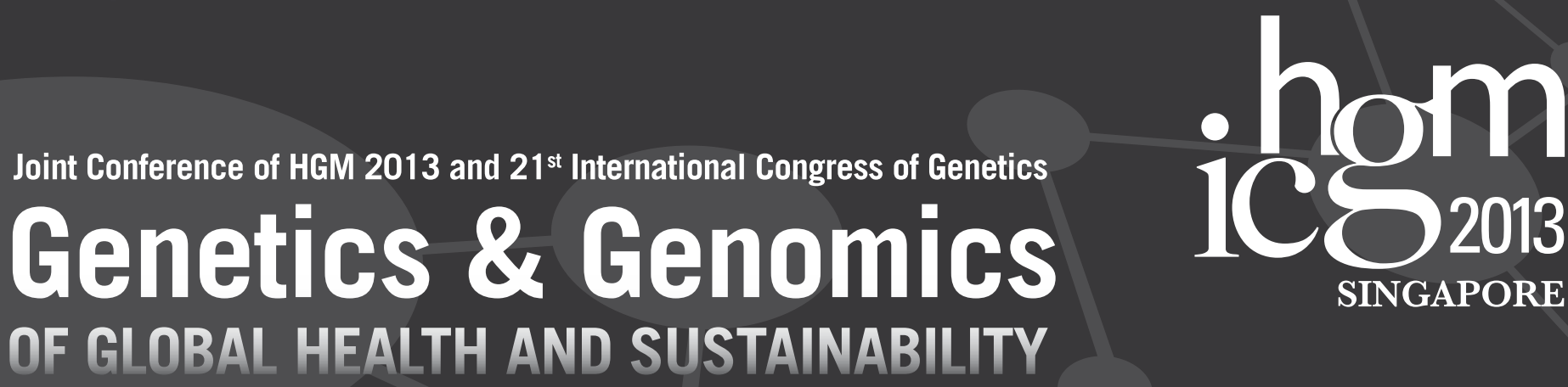

SINGAPORE

13-18 April 2013 I The Sands Expo and Convention Center, Marina Bay Sands

\section{The Convergence of Two Major Meetings}

Join experts worldwide to explore two of the most important issues in the $21^{\text {st }}$ century:

Human Health and Global Sustainability.

Key topics that will be discussed include:

- Human Genetics Medicine

- Sustainability

- Genome Medicine

- ELSI, Policy and Biobanking
- Genomes \& Techonologies

- Genetic Mechanisms

- Non-Human Genetics (Model Systems)

For more updates on key speakers and programme, visit our website at www.hgm2013-icg.org

For enquiries, email info@hgm2013-icg.org

\section{Register by 31 December 2012 and enjoy greater} savings with the Saver Rate!

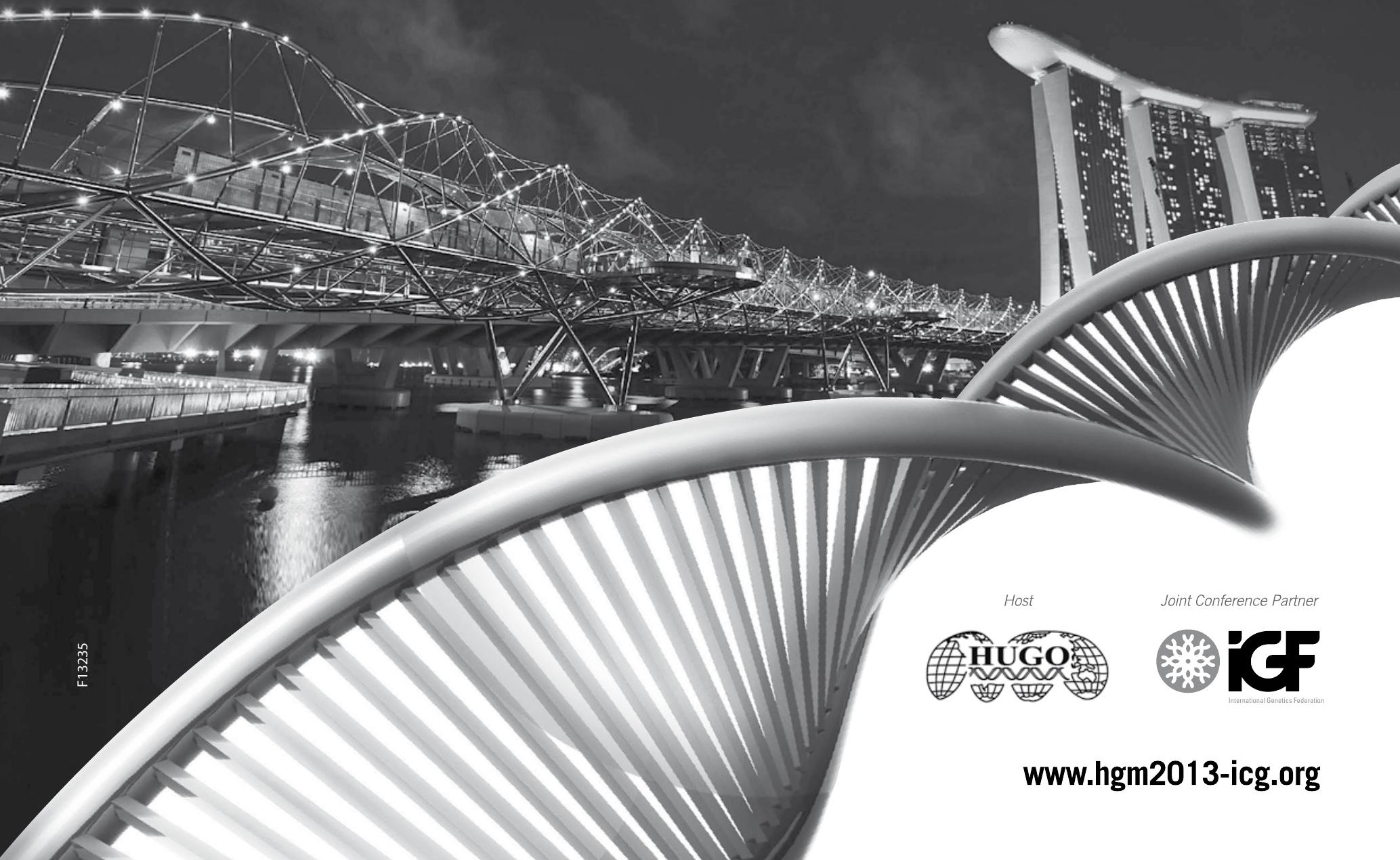




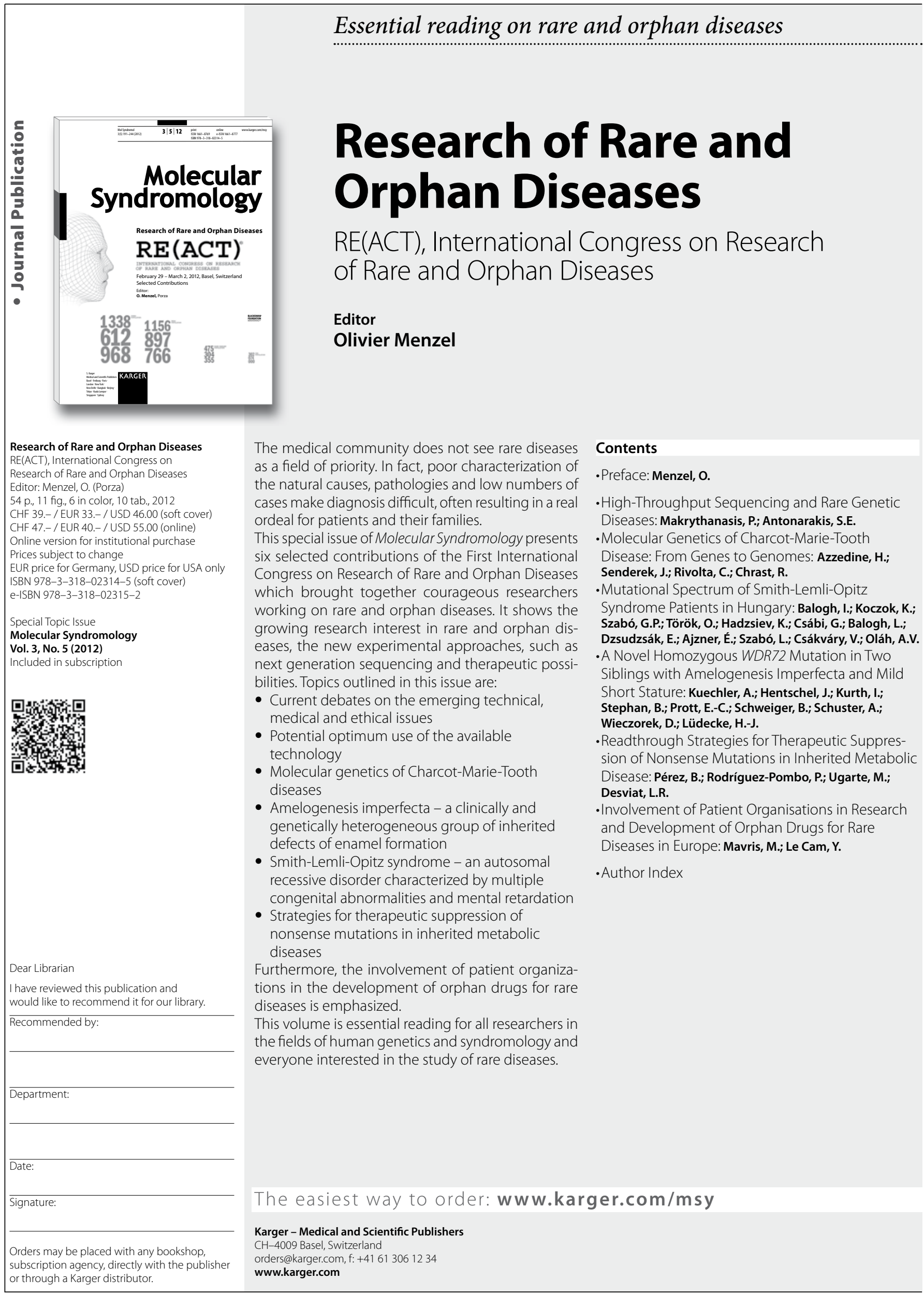




\section{The journal for researchers and clinicians in the field of fetal diseases}

\section{Fetal Diagnosis and Therapy}

Clinical Advances and Basic Research

New Editorial Team!

Editor-in-Chief

E. Gratacós, Barcelona

\section{Associate Editors}

F. Figueras, Barcelona

E. Hernández-Andrade, Detroit, Mi.

J.A. Hyett, Sydney

L. Lewi, Leuven

D. Paladini, Napoli

R.D. Wilson, Calgary

Official Organ of the 'International Fetal Medicine and Surgery Society' Official Organ of the International Society 'Fetus as a Patient'
Fetal Diagnosis and Therapy

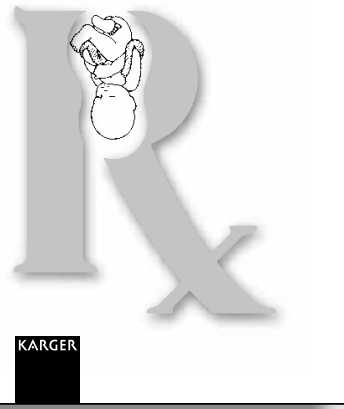

More information at

\section{www.karger.com/fdt}

- Pay-per-View and Subscriber Access to Full Text

- Full Table of Contents

- Full Editorial Board

- Free Abstracts and Selected Articles

- Online Sample Issue

- Submission/Guidelines for Authors

- Subscription Details

- Free Alert Service

- Online Library Recommendation

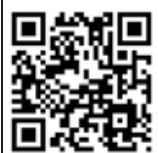

Fetal Diagnosis and Therapy

2013: Volumes 33, 34

4 issues per volume

Language: English

ISSN 1015-3837 (print)

ISSN 1421-9964 (online)

\section{Selected contributions}

- Are We Making a Real Difference? Update on 'Hidden Mortality' in the Management of Congenital Diaphragmatic Hernia: Mah, V.K.; Chiu, P.; Kim, P.C.W.

(Toronto, Ont.)

- Examining the Relationship between the Lung-to-Head Ratio Measured on Ultrasound and Lung Volumetry by Magnetic Resonance in Fetuses with Isolated Congenital Diaphragmatic Hernia: Sandaite, I.; Claus, F.; De Keyzer, F.; Donè, E.; Van Mieghem, T.; Gucciardo, L.; DeKoninck, P.; Jani, J.; Cannie, M.; Deprest, J.A. (Leuven)

- Turning the Pyramid of Prenatal Care: Nicolaides, K.H. (London)

- Can a 15-mm Cervical Length Cutoff Discriminate between Low and High Risk of Preterm Delivery in Women with Threatened Preterm Labor? Wulff, C.B.;

Ekelund, C.K.; Hedegaard, M.; Tabor, A. (Copenhagen)

- Prenatal Diagnosis, Management and Outcome of Fetal Dysrhythmia: A Tertiary Fetal Medicine Centre Experience over an Eight-Year Period: Rasiah, S.V.; Ewer, A.K.; Miller, P.; Kilby, M.D. (Birmingham)

- Preschool Neurobehavioral Outcome following Fetal Myelomeningocele Surgery: Danzer, E.; Gerdes, M.; Bebbington, M.W.; Koh, J.; Adzick, N.S.; Johnson, M.P. (Philadelphia, Pa.)

- Preterm Prelabor Rupture of Membranes and Fetal Survival after Minimally Invasive Fetal Surgery: A Systematic Review of the Literature: Beck, $\mathbf{v}$. (Leuven/Tübingen); Lewi, P.; Gucciardo, L.; Devlieger, R. (Leuven)

- Maternal Serum Placental Growth Factor in Prospective Screening for Aneuploidies at 8-13 Weeks' Gestation: Pandya, P. (London); Wright, D. (Plymouth); Syngelaki, A. (London); Akolekar, R. (Gillingham); Nicolaides, K.H. (London)
The first journal to focus on the fetus as a patient, Fetal Diagnosis and Therapy provides a wide range of biomedical specialists with a single source of report encompassing the common discipline of fetal medicine.

Fetal Diagnosis and Therapy offers a selection of peer-reviewed original research papers ranging in scope from basic and pathophysiologic investigations to clinical studies in fetal diagnosis and therapy. Furthermore, the journal features sections such as 'Mini-Reviews', where specific questions of clinical interest will be addresses by internationally renowned experts in the field, or 'Images in Fetal Medicine', which aims at exploiting the huge amount of images that the practice of fetal medicine generates, with particular interest in documenting cases with multimodal imaging. 


\section{Molecular
Syndromology}

\section{VACTERL Association}

This collection of articles describes the current medical and biological knowledge related to VACTERL/VATER association. VACTERL association is a fascinating condition involving malformations that can affect the skeletal, gastrointestinal (and genitourinary), cardiac, pulmonary, and renal systems. The disorder is also related to many other clinically and biologically related conditions. This publication presents cutting-edge summaries and research describing diverse aspects of these conditions, including the latest knowledge related to clinical aspects of disease manifestations and pathogenesis, embryology and developmental biology, key implicated signaling pathways, animal models of disease pathogenesis, techniques of molecular discovery related to the causes of human disease, and important considerations involving the differential diagnosis. This compendium should serve as a touchstone for future clinical and research endeavors as the growing body of medical research continues to unravel the mysteries of VACTERL association.

This collection is anticipated to be valuable to a diverse group of clinicians and researchers. First, by increasing the understanding of aspects of disease etiology and manifestations, the articles may help clinicians who encounter affected patients and families. Second, descriptions of the state-of-the art scientific knowledge may provide biological insight into current models of disease pathogenesis and inspire novel avenues of research. 